and his contributions though comparatively few were essentially practical.

Outside his professional work he had many interests. In his earlier life he was a keen amateur actor, and a great walker, both in England and on the Continent. He was a reader and student of history; his conversation was always stimulating, revealing the wide range of his knowledge.

In 1898 he married Fanny Mein, daughter of Dr. Charles Steele of Clifton and had three daughters, for whom great sympathy will be felt in their bereavement. To his wife's support and devotion he freely acknowledged much of his success and from her death in 1935 he was never quite the same man again.

His personality attracted a wide circle of life-long friendships and his loss will be deplored by many.

\title{
L. de BLASKOVICS
}

With the death of Ladislas de Blaskovics medical science, the Hungarian nation, our University and suffering humanity in general have sustained an immense loss.

Born in 1869, he took his M.D. degree in 1893. For a period of ten years he was assistant at the University Eye Clinic of Budapest and for twenty years Director of the Royal Hungarian State Eye Hospital. In 1928 he was appointed Professor of Ophthalmology and Director of the second University Eye Hospital in Budapest. Since my own retirement in June, 1936, he was my successor in the oldest chair in ordinary of the world, and Director of the two united University Eye Hospitals of Budapest.

He was a surgeon born. As early as 1892, in his student days, he drew attention to himself by his technical skill in the operations he performed on animals. On my proposal he joined the staff of the University Eye Clinic, where the extensive material at his disposal gave him ample opportunity to develop his surgical gifts. Later the State Eye Hospital with its 170 beds opened the way to independent work. His career followed in all things the lines laid down by Sir William Osler as desirable for a University Professor : first study, then research work, then instruction, and finally a welltimed retirement.

His scientific work covered the entire domain of Ophthalmology and was characterised by extreme and conscientious thoroughness. $\mathrm{He}$ achieved lasting results in many and various fields; thus it was he who proposed a new unit for the measurement of the vision: "oxyoptry," which replaces the one-minute test for the angle of vision by that of one degree. 
But his chief work remained operations on the eye. He discovered numerous new methods of which the best-known was that applied against ptosis and was recognised throughout the scientific world as a master of plastic surgery of the eyelids. His "Surgery of the Eye" went through several editions in Hungary; it was also published in German with the collaboration of Aladár Kreiker and is shortly to appear in an English edition.

As a man he was distinguished for his nobility of character, sincerity, honesty and sense of justice. He was patriotic, deeply religious, yet tolerant of other people's faith, tender with his patients and a true and faithful friend-a gentleman in the best sense of the world, who had not an enemy in the world. His work will be his best memorial.

EMILE DE GRósz.

\section{NOTES}

Death We regret to announce the death of Dr. J. M. Wheeler, of New York, on August 22, 1938. We hope to publish a memoir in our next number.

Appointments Miss E. E. CASs has been appointed Hon. Ophthalmic Surgeon to the New Sussex Hospital for Women and Children, Brighton.

MR. Joseph Minton has been elected Assistant Ophthalmic Surgeon to the West End Hospital for Nervous Diseases.

$\begin{array}{cl}\text { The } & \text { THE Council of the Ophthalmological Society } \\ \text { Treacher Collins } & \text { of the United Kingdom has instituted a prize of } \\ \text { Prize } & £ 100 \text {, awarded triennially, for the best essay }\end{array}$ submitted upon a subject selected by the Council. The prize is open to qualified medical practitioners of any nationality, and the essay is to be written in the English language. The subject for the first award is "Cerebro-spinal disease and its relation to the optic nerve."

The closing date for sending in essays for the first award is December 31, 1938, they should be sent to the Hon. Secretary, Ophthalmological Society of the United Kingdom, 5, Racquet Court, Fleet Street, London, E.C.4. 